\title{
Bosentan induces clinical and hemodynamic improvement in candidates for right-sided heart bypass surgery
}

\author{
Keiichi Hirono, MD, ${ }^{a}$ Naoki Yoshimura, MD, ${ }^{\mathrm{b}}$ Masato Taguchi, $\mathrm{PhD},{ }^{\mathrm{c}}$ Kazuhiro Watanabe, $\mathrm{MD},{ }^{\mathrm{a}}$ \\ Tsuneyuki Nakamura, MD, ${ }^{\mathrm{d}}$ Fukiko Ichida, $\mathrm{MD},{ }^{\mathrm{a}}$ and Toshio Miyawaki, $\mathrm{MD}^{\mathrm{a}}$
}

\begin{abstract}
Objective: To investigate the efficacy of bosentan in patients with single-ventricle physiology who were unable to undergo right-sided heart bypass surgery because of high pulmonary vascular resistance and pulmonary artery pressure.
\end{abstract}

\begin{abstract}
Methods: Eight patients with single-ventricle physiology ( 2 male and 6 female; aged 7 months to 5 years, median 1 year) were enrolled. Prior surgical interventions included pulmonary artery banding in 4 patients, Blalock-Taussig shunt operation in 2 patients, and bidirectional Glenn operation in 5 patients. Right-sided heart bypass surgery was contraindicated for all patients because of high pulmonary vascular resistance and pulmonary artery pressure.
\end{abstract}

Results: Bosentan therapy successfully reduced pulmonary artery pressure and pulmonary vascular resistance in all patients. Mean pulmonary artery pressure at baseline and after bosentan therapy was $21.1 \pm 7.2 \mathrm{~mm} \mathrm{Hg}$ and $11.9 \pm 4.1 \mathrm{~mm} \mathrm{Hg}$, respectively $(P<.01)$. Mean pulmonary vascular resistance index at baseline and after bosentan therapy was $5.7 \pm 3.3 \mathrm{U} / \mathrm{m}^{2}$ and $1.3 \pm 0.4 \mathrm{U} / \mathrm{m}^{2}$, respectively $(P<.01)$. Mean pulmonary vascular resistance/systemic vascular resistance at baseline and after bosentan therapy was $0.25 \pm 0.11$ and $0.07 \pm 0.03$, respectively $(P<.01)$. All patients had improved clinical symptoms and underwent successful Fontan operations.

Conclusion: Bosentan induces mid-term clinical and hemodynamic improvement in patients with singleventricle physiology and elevated pulmonary vascular resistance and pulmonary artery pressure. Bosentan therapy may increase the surgical options and improve outcomes in candidates for right-sided heart bypass surgery. (J Thorac Cardiovasc Surg 2010;140:346-51)

In recent years, new treatment strategies have largely improved the clinical status and life expectancy of patients with pulmonary artery hypertension (PAH). ${ }^{1}$ Bosentan, an oral dual endothelin ( $\mathrm{A}$ and $\mathrm{B}$ ) receptor antagonist, has been shown to be effective in patients with idiopathic $\mathrm{PAH}$ and PAH related to connective tissue disease, improving long-term quality of life..$^{2-4}$ During the past few years, small open-label studies have suggested that bosentan is safe and well tolerated in adults with congenital heart disease (CHD) and that it improves functional status and exercise capacity. ${ }^{5,6}$ These pilot studies triggered the first large randomized controlled trial of bosentan in patients with Eisenmenger syndrome, showing a beneficial short-term effect of bosentan on exercise capacity and hemodynamics without compromising systemic oxygen saturation. ${ }^{7}$

Nonetheless, there are few reports so far on the effect of bosentan on elevated pulmonary artery pressure (PAP) and

From the Department of Pediatrics, ${ }^{a}$ First Department of Surgery, ${ }^{b}$ and Department of Clinical Pharmacy, ${ }^{\mathrm{c}}$ University of Toyama, Japan; and Department of Pediatrics, ${ }^{\mathrm{d}}$ Kanazawa Medical University, Kanazawa, Japan.

Disclosures: None.

Received for publication Nov 2, 2009; revisions received Feb 4, 2010; accepted for publication March 21, 2010; available ahead of print May 3, 2010.

Address for reprints: Fukiko Ichida, MD, Department of Pediatrics, Faculty of Medicine, University of Toyama, 2630 Sugitani, Toyama, Toyama, 930-0194 Japan (E-mail: fukiko@med.u-toyama.ac.jp).

0022-5223/\$36.00

Copyright (c) 2010 by The American Association for Thoracic Surgery doi:10.1016/j.jtcvs.2010.03.023 pulmonary vascular resistance (PVR) in patients with single-ventricle (SV) physiology. Apostolopoulou and colleagues ${ }^{8}$ reported that bosentan induced clinical, exercise, and hemodynamic improvement in a 14-year-old patient with failing Fontan circulation, high PAP, and plastic bronchitis. ${ }^{8}$ Votava-Smith and colleagues ${ }^{9}$ used bosentan to treat PVR in a 10-year-old patient with SV physiology and a bidirectional Glenn shunt.

Thus, we hypothesized that endothelin may play an important role in maintaining vasoconstriction in SV physiology before and after right-sided heart bypass surgery, and that the endothelin receptor antagonist bosentan may induce hemodynamic improvement in patients with SV physiology with decreased PVR and PAP, which would increase the surgical options. This study examined the efficacy of bosentan in patients with SV physiology who were unable to undergo right-sided heart bypass surgery because of high PVR and PAP.

\section{MATERIALS AND METHODS Patients}

A total of 28 patients with SV physiology underwent cardiac catheterization to evaluate the indication for Fontan operation at the University Hospital of Toyama University between January 2006 and April 2009. Among them, 8 patients were unable to undergo right-sided heart bypass surgery because of high PVR $\left(\geq 3 \mathrm{U} / \mathrm{m}^{2}\right)$ and mean PAP $(\geq 18 \mathrm{~mm} \mathrm{Hg})$. The remaining 20 patients, who did not have high PVR $\left(<3 \mathrm{U} / \mathrm{m}^{2}\right)$ and mean PAP ( $<18 \mathrm{~mm} \mathrm{Hg}$ ), underwent Fontan operation successfully and were designated the non-PAH group. 


\section{Abbreviations and Acronyms \\ $\mathrm{CHD}=$ congenital heart disease \\ NYUPHFI $=$ New York University Pediatric Heart Failure Index \\ PAH = pulmonary artery hypertension \\ PAP = pulmonary artery pressure \\ PVR = pulmonary vascular resistance \\ $\mathrm{SV} \quad=$ single ventricle}

The degree of heart failure was quantified using the New York University Pediatric Heart Failure Index (NYUPHFI). ${ }^{10}$ This score is derived by the linear combination of scores based on symptoms, physical signs, and medical regimen (Table 1). Healthy children without heart failure are expected to score low (<2 points). ${ }^{10}$ All enrolled patients had PAH related to CHD with or without prior surgical repair and fixed elevated PVR that precluded further surgical intervention.

Care was taken to exclude other causes of pulmonary hypertension, such as pulmonary arterial hypoplasia, hypoventilation, and lung or liver disease. Patients had no treatment regimen changes within the last month before enrollment and during the study period, aside from the addition of bosentan treatment. No patients were taking epoprostenol, glibenclamide, or cyclosporine, to avoid drug interactions, or calcium channel blockers, because they were unresponsive to vasodilators. All patients were clinically evaluated once every month by electrocardiography, echocardiography, oxygen saturation measurement, and NYUPHFI score assessment. Liver enzyme levels were measured every 2 months in patients treated with bosentan.

The research ethics committee of the University Hospital of Toyama approved the study. Written informed consent was obtained from parents after the purpose and procedures of the study were fully explained.

\section{Study Design}

Patients started a twice daily oral bosentan regimen of 0.5 to $1 \mathrm{mg} / \mathrm{kg}$ per dose. The dose of bosentan was increased 0.5 to $1 \mathrm{mg} / \mathrm{kg}$ every 4 weeks until reaching $3 \mathrm{mg} / \mathrm{kg}$ per dose.

All patients were evaluated before initiation and after bosentan treatment regarding history and subjected to clinical examination to define NYUPHFI, an unstructured interview including questions about perceived well-being and exercise ability, and evaluations of maximal and submaximal exercise capacity. Complete hemodynamic studies were simultaneously performed before and after bosentan treatment. Drug safety was evaluated bimonthly by monitoring adverse events, such as flushing and nasal congestion; laboratory tests, such as liver function tests and hemoglobin concentration; electrocardiogram; vital signs; pulse oximetry recordings; and discontinuations.

Cardiac catheterization was performed just before starting bosentan and after bosentan therapy to select surgical options; this was performed under local anesthesia with additional intravenous sodium thiopental. Similarly, cardiac catheterization was performed in the non-PAH group to evaluate the indication of the Fontan operation. Blood gas analysis showed normal partial carbon dioxide acid base status during cardiac catheterization. Pulmonary arterial, right atrial, and pulmonary capillary wedge pressures and systemic pressures were recorded. Systemic and pulmonary arterial and venous saturations were obtained to calculate cardiac outputs with the Fick principle and table-derived oxygen consumption values. ${ }^{11}$ Oxygen saturations obtained from pulmonary veins, when possible, or several pulmonary capillary wedge positions were used to calculate pulmonary venous oxygen content. For great artery level shunts, oxygen saturations from both distal pulmonary arteries were used to calculate pulmonary arterial oxygen
TABLE 1. New York University Pediatric Heart Failure Index Heart failure severity determined from signs and symptoms, medical regimen, and ventricular physiology

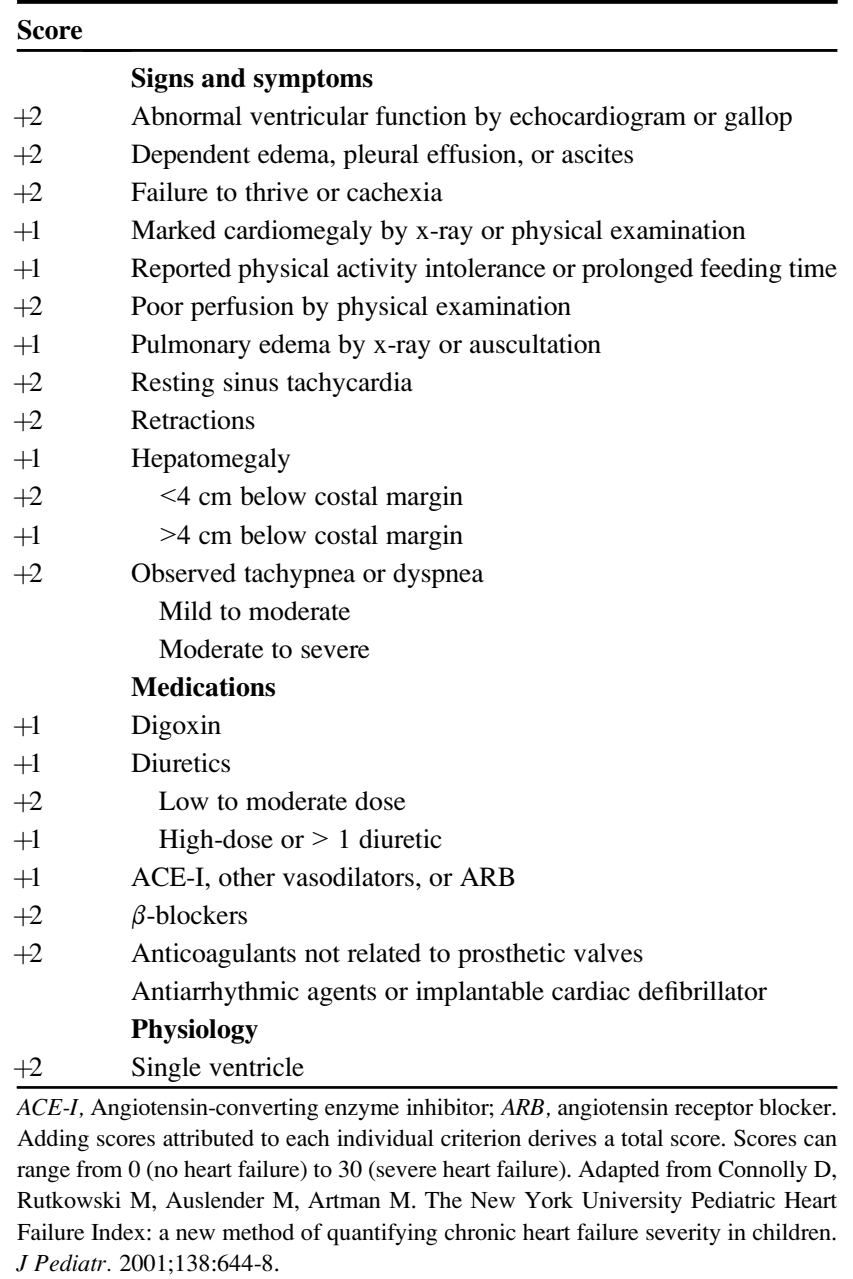

content. Calculation of systemic flow was adequate because oxygen saturations were equal throughout the systemic circuit in all patients. The transpulmonary pressure gradient was defined as the difference between mean PAP and mean pulmonary capillary wedge or left atrial pressure. Pulmonary and systemic vascular resistance indices were calculated with the standard formula. ${ }^{12}$ Baseline catheterization studies included hyperoxia or vasodilator challenge to define fixed elevated PVR. Brain natriuretic peptide was quantified at the time of cardiac catheterization. All patients underwent lung perfusion scintigraphy to assess the right-to-left shunt before bosentan therapy. ${ }^{13}$ We combined these data and analyzed pulmonary hemodynamics.

\section{Statistical Analysis}

All results were expressed as mean \pm standard deviation. Paired $t$ test was used to test for significance of the same parameter within the same group. If data did not follow a normal distribution, the paired $t$ test was replaced by a Wilcoxon signed-rank test. When the data followed a normal distribution determined by Shapiro-Wilks test, comparisons between 2 groups were performed using an unpaired Student $t$ test or a Welch's test depending on equal or unequal variance. If the data did not follow a normal distribution, then a Mann-Whitney $U$ test was used. All $P$ values were 2-tailed. 
TABLE 2. Baseline clinical and functional characteristics of patients

\begin{tabular}{|c|c|c|c|c|c|c|c|}
\hline Patient & Diagnosis & Age & Gender & $\begin{array}{c}\text { Pulse } \\
\text { oximetry }(\%)\end{array}$ & Symptoms & Medications & NYUPHFI \\
\hline 1 & $\begin{array}{l}\text { Asplenia, SV, DORV, } \\
\text { CoA, TAPVR }\end{array}$ & $9 \mathrm{mo}$ & $\mathrm{F}$ & 84 & Cyanosis & Diuretics, warfarin, aspirin, beraprost & 9 \\
\hline 2 & $\begin{array}{l}\text { Asplenia, SV, MA, } \\
\text { DORV, TAPVR }\end{array}$ & $8 \mathrm{mo}$ & $\mathrm{F}$ & 71 & DOE, cyanosis & Diuretics, aspirin, beraprost & 8 \\
\hline 3 & $\begin{array}{l}\text { Asplenia, SV, DORV, } \\
\text { PS, TAPVR }\end{array}$ & $1 \mathrm{y}$ & $\mathrm{F}$ & 81 & DOE, cyanosis & $\begin{array}{l}\text { Diuretics, warfarin, } \\
\text { aspirin, beraprost, ACE-I, } \\
\text { sildenafil }\end{array}$ & 12 \\
\hline 4 & $\begin{array}{l}\text { Asplenia, SV, CAVC, } \\
\text { DORV, PS, TAPVR }\end{array}$ & $7 \mathrm{mo}$ & M & 80 & Cyanosis & $\begin{array}{l}\text { Diuretics, warfarin, beraprost, } \\
\text { aspirin, ACE-I }\end{array}$ & 9 \\
\hline 5 & HLHS & $10 \mathrm{mo}$ & $\mathrm{F}$ & 74 & Cyanosis & $\begin{array}{l}\text { Diuretics, warfarin, } \\
\text { aspirin, beraprost, digoxin, ACE-I, } \\
\beta \text {-blocker }\end{array}$ & 11 \\
\hline 6 & HLHS & $2 \mathrm{y}$ & M & 75 & Cyanosis & $\begin{array}{l}\text { Diuretics, warfarin, } \\
\text { aspirin, beraprost, digoxin }\end{array}$ & 11 \\
\hline 7 & HLHS & $5 \mathrm{y}$ & $\mathrm{F}$ & 86 & DOE, cyanosis & $\begin{array}{l}\text { Diuretics, warfarin, } \\
\text { aspirin, beraprost, } \beta \text {-blocker, } \\
\text { pimobendan }\end{array}$ & 15 \\
\hline 8 & SV, DORV, d-MGA & $1 \mathrm{y}$ & $\mathrm{F}$ & 72 & Cyanosis & $\begin{array}{l}\text { Diuretics, warfarin, } \\
\text { aspirin, beraprost, ACE-I, ARB }\end{array}$ & 9 \\
\hline
\end{tabular}

NYUPHFI, New York University Pediatric Heart Failure Index; SV, single ventricle; DORV, double outlet right ventricle; CoA, coarctation of aorta; TAPVR, total anomalous of pulmonary venous return; $M A$, mitral atresia; $P S$, pulmonary stenosis; $C A V C$, complete atrioventricular canal; $H L H S$, hypoplastic left heart syndrome; $d-M G A$, d-malposition of the great arteries; $D O E$, dyspnea on exertion; $A C E-I$, angiotensin-converting enzyme-inhibitor; $A R B$, angiotensin receptor blocker.

\section{RESULTS}

\section{Patient Clinical Characteristics}

All 8 patients started bosentan therapy between January 2006 and April 2009, with follow-up through September 2009. Tables 2 and 3 shows the clinical characteristics of the 8 patients with $\mathrm{PAH}$ related to $\mathrm{CHD}$, including descriptions of the procedures/surgeries performed. All patients had PAH associated with relative overcirculation to hypoplastic pulmonary vasculature. The 8 patients had higher mean PAP $(P<.01)$, higher PVR $(P<.01)$, and smaller pulmonary artery index $(P<.01)$ compared with the non-PAH group (Table 4). All patients were significantly symptomatic (NYUPHFI score $12.5 \pm 2.3$ ) and cyanotic with pulse oximetry (mean $77.9 \% \pm 5.6 \%$ ). All patients had taken beraprost before bosentan therapy (median 5.5 months, 1-65 months), but clinical and hemodynamic improvement was not observed because of relative overcirculation to a diminished pulmonary vasculature.

\section{Treatment Effect}

Clinical and hemodynamic evaluation was performed at baseline and after 5 to 17 months (mean 8 months). Results at baseline and after bosentan therapy were as follows: mean main PAP: $21.1 \pm 7.2 \mathrm{~mm} \mathrm{Hg}$ and $11.9 \pm 4.1 \mathrm{~mm} \mathrm{Hg}$, respectively $(P=.0014)$; PVR: $5.7 \pm 3.3 \mathrm{U} / \mathrm{m}^{2}$ and $1.3 \pm$ $0.4 \mathrm{U} / \mathrm{m}^{2}$, respectively $(P=.0035)$; PVR/systemic vascular resistance: $0.25 \pm 0.11$ and $0.07 \pm 0.03$, respectively $(P=.0009)$ (Table 4). However, cardiac index, Qp/Qs, pulse oximetry, and hemoglobin were not significantly changed, but brain natriuretic peptide and NYUPHFI improved significantly. After bosentan therapy, 3 patients underwent bidirectional Glenn surgery and all 8 patients successfully underwent Fontan surgery (Table 3).

After the Fontan operation, all patients continued bosentan therapy. However, 2 patients (numbers 1 and 2) were admitted to the hospital once because of protein-losing enteropathy, but they recovered completely with heparin therapy (Tables 2 and 3). The remaining 6 patients had no complications, including protein-losing enteropathy, plastic bronchitis, and liver dysfunction. The average NYUPHFI score in the 8 patients improved to $6.0 \pm 0.5$ after Fontan surgery.

\section{Safety and Tolerability}

All patients maintained adequate serum bosentan concentrations during therapy (Table 5). As we administered initial doses of bosentan adjusting for patients' body weight, tachypnea and chest discomfort did not occur in any of the patients. Abnormal hepatic function, interference with the international normalized ratio, and other adverse events were not observed in this study.

\section{DISCUSSION}

We show that bosentan therapy reduces PAP and PVR in patients with SV physiology who are unable to undergo right-sided heart bypass surgery because of high PVR and PAP. With the support of bosentan therapy, the bidirectional Glenn procedure was performed in 3 cases, and the Fontan operation was completed successfully in all 8 cases. 
TABLE 3. Palliative surgery before bosentan and latest operations after bosentan

\begin{tabular}{|c|c|c|c|c|c|c|}
\hline Patients & Diagnosis & Age & Prior operation & $\begin{array}{c}\text { Starting age of } \\
\text { bosentan }\end{array}$ & Age & $\begin{array}{c}\text { After bosentan } \\
\text { therapy }\end{array}$ \\
\hline 1 & $\begin{array}{l}\text { Asplenia, SV, DORV, } \\
\text { CoA, TAPVR }\end{array}$ & $\begin{array}{l}2 \mathrm{~d} \\
23 \mathrm{~d} \\
7 \mathrm{mo} \\
8 \mathrm{mo}\end{array}$ & $\begin{array}{l}\text { CoA repair, } \mathrm{PAB} \\
\text { re-PAB } \\
\text { re-re-PAB } \\
\text { TAPVR repair }\end{array}$ & $9 \mathrm{mo}$ & $\begin{array}{l}1 \mathrm{y} \\
2 \mathrm{y}\end{array}$ & $\begin{array}{l}\text { BDG } \\
\text { Fontan }\end{array}$ \\
\hline 2 & $\begin{array}{l}\text { Asplenia, SV, MA, } \\
\text { DORV, TAPVR }\end{array}$ & $\begin{array}{l}1 \mathrm{mo} \\
2 \mathrm{mo}\end{array}$ & $\begin{array}{l}\text { PAB } \\
\text { TAPVR repair }\end{array}$ & $8 \mathrm{mo}$ & $\begin{array}{c}11 \mathrm{mo} \\
2 \mathrm{y}\end{array}$ & $\begin{array}{l}\text { BDG } \\
\text { Fontan }\end{array}$ \\
\hline 3 & $\begin{array}{l}\text { Asplenia, SV, DORV, } \\
\text { PS, TAPVR }\end{array}$ & $\begin{array}{l}19 \mathrm{~d} \\
1 \mathrm{y}\end{array}$ & $\begin{array}{l}\text { TAPVR repair } \\
\text { Right modified BT shunt }\end{array}$ & $1 \mathrm{y}$ & $\begin{array}{l}2 \mathrm{y} \\
3 \mathrm{y}\end{array}$ & $\begin{array}{l}\text { BDG } \\
\text { Fontan }\end{array}$ \\
\hline 4 & $\begin{array}{l}\text { Asplenia, SV, CAVC, } \\
\text { DORV, PS, TAPVR }\end{array}$ & $\begin{array}{l}2 \mathrm{mo} \\
1 \mathrm{y}\end{array}$ & $\begin{array}{l}\text { CAVVP } \\
\text { BDG }\end{array}$ & $7 \mathrm{mo}$ & $2 \mathrm{y}$ & Fontan \\
\hline 5 & HLHS & $\begin{array}{l}2 \mathrm{~d} \\
15 \mathrm{~d} \\
4 \mathrm{mo} \\
8 \mathrm{mo}\end{array}$ & $\begin{array}{l}\text { PTAV } \\
\text { Bilateral PAB } \\
\text { Norwood, MVP } \\
\text { Right BDG, intrapulmonary artery } \\
\quad \text { septation* }\end{array}$ & $10 \mathrm{mo}$ & $2 \mathrm{y}$ & Fontan \\
\hline 6 & HLHS & $\begin{array}{l}7 \mathrm{~d} \\
7 \mathrm{mo}\end{array}$ & $\begin{array}{l}\text { Norwood } \\
\text { BDG }\end{array}$ & $2 y$ & $2 y$ & Fontan \\
\hline 7 & HLHS & $\begin{array}{l}8 \mathrm{~d} \\
8 \mathrm{mo} \\
1 \mathrm{y} \\
2 \mathrm{y} \\
2 \mathrm{y}\end{array}$ & $\begin{array}{l}\text { Norwood } \\
\text { Left modified BT shunt } \\
\text { Right modified BT shunt } \\
\text { BDG } \\
\text { PMI }\end{array}$ & $5 y$ & $6 y$ & Fontan, CRT $\dagger$ \\
\hline 8 & SV, DORV, d-MGA & $\begin{array}{l}1 \mathrm{mo} \\
7 \mathrm{mo}\end{array}$ & $\begin{array}{l}\text { PAB } \\
\text { BDG, ASD enlargement, re-PAB }\end{array}$ & $1 \mathrm{y}$ & $2 y$ & DKS, Fontan \\
\hline
\end{tabular}

$S V$, Single ventricle; $D O R V$, double outlet right ventricle; $C O A$, coarctation of aorta; $T A P V R$, total anomalous of pulmonary venous return; $M A$, mitral atresia; $P S$, pulmonary stenosis; $P A B$, pulmonary artery banding; $C A V C$, complete atrioventricular canal; $H L H S$, hypoplastic left heart syndrome; $d-M G A$, d-malposition of the great arteries; $C A V V P$, common atrial ventricular valvular plasty; $B D G$, bidirectional Glenn; $P T A V$, percutaneous transluminal balloon aortic valvuloplasty; $M V P$, mitral valvular plasty; $B T$, Blalock-Taussig; $P M I$, pacemaker implantation; $A S D$, atrial septal defect; $C R T$, cardiac resynchronization therapy; $D K S$, Damus-Kaye-Stansel. *Patient 4 had intrapulmonary artery septation and right BDG caused by left pulmonary artery stenosis. The flow of the superior vena cava was connected to the right pulmonary artery, and the flow of the left pulmonary artery was supplied by the right ventricular pulmonary artery shunt. ${ }^{24} \dagger$ Patient 7 had dysrhythmia and heart failure caused by ventricular dyssynchrony before the Fontan operation. Cardiac resynchronization therapy was performed with Fontan operation.

Elevated PAP greater than 18 to $20 \mathrm{~mm} \mathrm{Hg}$ and PVR greater than 3 or 4 Woods units are known risk factors for death or failure of anastomosis in patients with bidirectional Glenn shunts. ${ }^{14,15}$
Endothelin has been implicated in the pathogenesis of pulmonary hypertension secondary to CHD. Endothelin mediates vasoconstriction and induces vascular smooth muscle cell contraction, proliferation, and inflammation. Increased

TABLE 4. Hemodynamic parameters before and after bosentan treatment

\begin{tabular}{|c|c|c|c|c|c|}
\hline & $\begin{array}{c}\text { Non-PAH group } \\
\quad(\mathbf{n}=\mathbf{2 0}) \\
\end{array}$ & $\begin{array}{c}\text { Before bosentan } \\
\text { treatment }(n=8)\end{array}$ & $\begin{array}{c}\text { After bosentan } \\
\text { treatment }(n=8)\end{array}$ & Percentage change $(\%)$ & $P$ valu \\
\hline Body weight (kg) & $7.3 \pm 1.2$ & $7.1 \pm 1.8$ & $9.1 \pm 2.1$ & +27.9 & .0088 \\
\hline Body surface area $\left(\mathrm{m}^{2}\right)$ & $0.36 \pm 0.05$ & $0.34 \pm 0.09$ & $0.45 \pm 0.09$ & +32.4 & .0171 \\
\hline Main mean PAP $(\mathrm{mm} \mathrm{Hg})$ & $12.4 \pm 4.1$ & $21.1 \pm 7.2$ & $11.9 \pm 4.1$ & -43.8 & .0014 \\
\hline $\operatorname{PVR}\left(\mathrm{U} / \mathrm{m}^{2}\right)$ & $1.50 \pm 0.57$ & $5.72 \pm 3.34$ & $1.30 \pm 0.43$ & -77.3 & .0035 \\
\hline PVR/SVR & $0.08 \pm 0.02$ & $0.25 \pm 0.11$ & $0.07 \pm 0.03$ & -72.0 & .0009 \\
\hline PA index & $412 \pm 154.0$ & $237 \pm 119.2$ & $242.1 \pm 81.6$ & +2.0 & .4180 \\
\hline Cardiac index $\left(\mathrm{L} / \mathrm{min} / \mathrm{m}^{2}\right)$ & $3.36 \pm 0.80$ & $3.59 \pm 1.12$ & $3.16 \pm 1.05$ & -12.0 & .1962 \\
\hline Qp/Qs & $1.47 \pm 0.60$ & $0.93 \pm 0.44$ & $1.06 \pm 0.42$ & +14.0 & .2286 \\
\hline $\mathrm{Hb}(\mathrm{g} / \mathrm{dL})$ & $15.6 \pm 1.3$ & $15.3 \pm 1.4$ & $15.5 \pm 2.6$ & +1.0 & .4266 \\
\hline Pulse oxymetry (\%) & $79.6 \pm 5.7$ & $77.9 \pm 5.6$ & $83.5 \pm 4.8$ & +7.2 & .0164 \\
\hline $\mathrm{BNP}(\mathrm{pg} / \mathrm{mL})$ & $123.4 \pm 253.1$ & $221.5 \pm 189.6$ & $65.4 \pm 70.9$ & -70.5 & .0367 \\
\hline NYUPHFI score & $5.6 \pm 1.6$ & $10.5 \pm 2.3$ & $8.0 \pm 2.4$ & -23.8 & .0026 \\
\hline
\end{tabular}

$P A H$, Pulmonary artery hypertension; $P A P$, pulmonary artery pressure; $P V R$, pulmonary vascular resistance; $S V R$, systemic vascular resistance; $P A$, pulmonary artery; $Q p$, pulmonary blood flow; $Q s$, systemic blood flow; $H b$, hemoglobin; $B N P$, brain natriuretic peptide; NYUPHFI, New York University Pediatric Heart Failure Index. Data are mean \pm standard deviation. $P$ value is derived from comparison of before and after bosentan treatment. 
TABLE 5. Dosage and side effects of bosentan

\begin{tabular}{|c|c|c|c|c|c|}
\hline Patient & Duration & $\begin{array}{c}\text { Dosage } \\
(\mathrm{mg} / \mathrm{kg} / \mathrm{d})\end{array}$ & $\begin{array}{c}\text { Concentration } \\
(\text { trough) }(\mathrm{ng} / \mathrm{mL})\end{array}$ & $\begin{array}{c}\text { Concentration } \\
(\text { peak })(\mathrm{ng} / \mathrm{mL})\end{array}$ & Adverse effect \\
\hline 1 & $1 \mathrm{y}$ & 1 & 27.6 & 78.6 & None \\
\hline 2 & $1 \mathrm{y}$ & 2 & 27.5 & 76.6 & None \\
\hline 3 & $1 \mathrm{y}$ & 2 & 102.1 & 522.8 & None \\
\hline 4 & $10 \mathrm{mo}$ & 2 & 17.3 & 136.1 & None \\
\hline 5 & $8 \mathrm{mo}$ & 3 & 55.8 & 704.0 & None \\
\hline 6 & $1 \mathrm{y}$ & 2 & 52.3 & 365.8 & None \\
\hline 7 & $7 \mathrm{mo}$ & 3 & 187.2 & 220.6 & None \\
\hline 8 & $6 \mathrm{mo}$ & 2 & 147.3 & 399.4 & None \\
\hline
\end{tabular}

levels of endothelin-1 have been found in plasma and lung biopsies of patients with CHD and PAH. ${ }^{16,17}$ Elevated PAP and excessive pulmonary flow have been associated with elevated endothelin-1 levels in experimental models and in patients with CHD. ${ }^{18,19}$

The use of bosentan in pediatric patients was evaluated in a prospective, open-label pharmacokinetic study in 19 children with idiopathic PAH or PAH related to CHD. ${ }^{20}$ Bosen$\tan$ treatment for 12 weeks resulted in hemodynamic improvement and formed the basis of the current dosing schedule for the drug in pediatric patients. ${ }^{20}$ In a retrospective study of 86 pediatric patients primarily with idiopathic $\mathrm{PAH}$ or PAH related to CHD, bosentan improved or maintained World Health Organization functional class and improved hemodynamics. ${ }^{21}$ Kaplan-Meier estimates of survival at 1 and 2 years were $98 \%$ and $91 \%$, respectively. In another retrospective study of 40 pediatric patients, bosentan helped stabilize children with idiopathic PAH, but intravenous epoprostenol was also needed by $60 \%$. Children with PAH related to other conditions improved. ${ }^{22}$

It has been reported that plasma endothelin-1 is elevated and adrenomedullin is decreased after Fontan operations, and an imbalance between endothelin- 1 and adrenomedullin might induce vasoconstriction. ${ }^{23}$ There was a positive correlation between endothelin-1 levels and PVR. ${ }^{23}$ Although we did not examine the serum level of endothelin, the bosentan doses used in this study were efficacious and of benefit to patients with Fontan circulation.

These results suggest that bosentan may induce hemodynamic improvement in patients with SV physiology with decreased PVR and PAP, thus increasing the surgical options. Further, endothelin may play an important role in maintaining vasoconstriction in SV physiology before and after right-sided heart bypass surgery.

\section{Study Limitations}

Within a few months of starting bosentan therapy, some of our patients had surgical procedures that may have had slowly developing favorable effects on PVR. However, catheterization data before starting bosentan showed fixed elevated PVR even on hyperoxia or vasodilator challenge, so favorable effects on PVR cannot be explained only by delayed effect of before surgical procedures. Our study was limited to a small number of patients. Larger, placebocontrolled studies with long-term administration of bosentan are needed to assess the optimal doses and possible therapeutic role of bosentan in this patient population.

\section{CONCLUSIONS}

Bosentan therapy reduced PAP and PVR and improved clinical symptoms and exercise tolerance in all cases. Bosentan induced mid-term clinical and hemodynamic improvement in patients with SV physiology with increased PVR. Bosentan therapy may increase the surgical options and improve the outcome in Fontan candidates with increased PVR secondary to diminished pulmonary vasculature and relative pulmonary overcirculation.

The authors thank Neil Bowles, Hironori Matsuhisa, Chisato Akita, Keiichirou Uese, Watanabe-Ozawa Sayaka, Keijirou Ibuki, and Kazuyoshi Saito for assistance.

\section{References}

1. Galiè N, Torbicki A, Barst R, Dartevelle P, Haworth S, Higenbottam T, et al. Guidelines on diagnosis and treatment of PAH. The Task Force on Diagnosis and Treatment of Pulmonary Arterial Hypertension of the European Society of Cardiology. Eur Heart J. 2004;25:2243-78.

2. Rubin LJ, Badesch DB, Barst RJ, Galie N, Black CM, Keogh A, et al. Bosentan therapy for pulmonary arterial hypertension. N Engl J Med. 2002;346:896-903.

3. Galiè N, Seeger W, Naeije R, Simonneau G, Rubin LJ. Comparative analysis of clinical trials and evidence-based treatment algorithm in pulmonary arterial hypertension. J Am Coll Cardiol. 2004;43:81-8.

4. Channick RN, Simonneau G, Sitbon O, Robbins IM, Frost A, Tapson VF, et al. Effects of the dual endothelin receptor antagonist bosentan in patients with pulmonary hypertension: a randomized placebo-controlled study. Lancet. 2001; 358:1119-23.

5. Gatzoulis MA, Rogers P, Li W, Harries C, Cramer D, Ward S, et al. Safety and tolerability of bosentan in adults with Eisenmenger physiology. Int $J$ Cardiol. 2005;98:147-51.

6. Schulze-Neick I, Gilbert N, Ewert R, Witt C, Gruenig E, Enke B, et al. Adult patients with congenital heart disease and pulmonary hypertension: first open prospective multicenter study of bosentan therapy. Am Heart J. 2005;150: 716.

7. Galiè N, Beghetti M, Gatzoulis MA, Granton J, Berger RM, Lauer A, et al. Bosentan therapy in patients with Eisenmenger syndrome. A multicenter, double-blind, randomized, placebo controlled study. Circulation. 2006;114:48-54. 
8. Apostolopoulou SC, Papagiannis J, Rammos S. Bosentan induces clinical, exercise and hemodynamic improvement in a pre-transplant patient with plastic bronchitis after Fontan operation. J Heart Lung Transplant. 2005;24:1174-6.

9. Votava-Smith JK, Perens GS, Alejos JC. Bosentan for increased pulmonary vascular resistance in a patient with single ventricle physiology and a bidirectional Glenn shunt. Pediatr Cardiol. 2007;28:314-6.

10. Connolly D, Rutkowski M, Auslender M, Artman M. The New York University Pediatric Heart Failure Index: a new method of quantifying chronic heart failure severity in children. J Pediatr. 2001;138:644-8.

11. Bridges ND, O'Lauhlin MP, Mullins CE, Freed MD. In: Allen HD, Gutgesell HP, Clark EB, Driscoll DJ, eds. Moss and Adams Heart Disease in Infants, Children, and Adolescents. Cardiac catheterization, angiography, and intervention, Volume 1. Baltimore: Williams \& Wilkins; 2001:276-324

12. Grossman W. Clinical measurement of vascular resistance and assessment of vasodilator drugs. In: Grossman W, ed. Cardiac Catheterization and Angiography. Philadelphia: Lea and Febiger; 1991:143-51.

13. Cloutier A, Ash JM, Smallhorn JF, Williams WG, Trusler GA, Rowe RD, et al. Abnormal distribution of pulmonary blood flow after the Glenn shunt or Fontan procedure: risk of development of arteriovenous fistulae. Circulation. 1985;72: 471-9.

14. Alejos JC, Williams RG, Jarmakani JM, Galindo AJ, Isabel-Jones JB, Drinkwater D, et al. Factors influencing survival in patients undergoing the bidirectional Glenn anastomosis. Am J Cardiol. 1995;75:1048-50.

15. Pridjian AK, Mendelsohn AM, Lupinetti FM, Beekman RH 3rd, Dick M 2nd, Serwer G, et al. Usefulness of the bidirectional Glenn procedure as a staged reconstruction for the functional single ventricle. Am J Cardiol. 1993;71:959-62.

16. Lutz J, Gorenflo M, Habighorst M, Vogel M, Lange PE, Hocher B. Endothelin-1- and endothelin-receptors in lung biopsies of patients with pulmonary hypertension due to congenital heart disease. Clin Chem Lab Med. 1999;37: 423-8.

17. Yoshibayashi M, Nishioka K, Nakao K, Saito Y, Matsumura M, Ueda T, et al Plasma endothelin concentrations in patients with pulmonary hypertension associated with congenital heart defects. Evidence for increased production of endothelin in pulmonary circulation. Circulation. 1991;84:2280-5.

18. Fratz S, Geiger R, Kresse H, Roemer G, Hennig M, Sebening W, et al. Pulmonary blood pressure, not flow, is associated with net endothelin-1 production in the lungs of patients with congenital heart disease and normal pulmonary vascular resistance. J Thorac Cardiovasc Surg. 2003;126:1724-9.

19. Vincent JA, Ross RD, Kassab J, Hsu JM, Pinsky WW. Relation of elevated plasma endothelin in congenital heart disease to increased pulmonary blood blow. Am J Cardiol. 1993;71:1204-7.

20. Barst RJ, Ivy D, Dingemanse J, Widlitz A, Schmitt K, Doran A, et al. Pharmacokinetics, safety, and efficacy of bosentan in pediatric patients with pulmonary arterial hypertension. Clin Pharmacol Ther. 2003;73:372-82.

21. Rosenzweig EB, Ivy DD, Widlitz A, Doran A, Claussen LR, Yung D, et al. Effects of long-term bosentan in children with pulmonary arterial hypertension. $J$ Am Coll Cardiol. 2005;46:697-704.

22. Maiya S, Hislop AA, Flynn Y, Haworth SG. Response to bosentan in children with pulmonary hypertension. Heart. 2006;92:664-70.

23. Hiramatsu T, Imai Y, Takanashi Y, Seo K, Terada M, Aoki M, et al. Time course of endothelin-1 and adrenomedullin after the Fontan procedure. Ann Thorac Surg. 1999;68:169-72.

24. Sakamoto K, Ikai A, Fujimoto Y, Ota N. Novel surgical approach 'intrapulmonary-artery septation' for Fontan candidates with unilateral pulmonary arterial hypoplasia or pulmonary venous obstruction. Interact Cardiovasc Thorac Surg. 2007;6:150-4. 